\title{
Selenium deficiency as a model of experimental pre-eclampsia in rats
}

\author{
J Vanderlelie, K Venardos and A V Perkins \\ School of Health Science, Griffith University Gold Coast Campus, Southport, QLD 9726, Australia \\ Correspondence should be addressed to T Perkins; Email: a.perkins@griffith.edu.au
}

\begin{abstract}
Epidemiological studies and in vitro analysis demonstrate correlations between selenium status and human pre-eclampsia (PET). Selenium is an essential component in the anti-oxidant proteins glutathione peroxidase and thioredoxin reductase, which are produced in lower amounts in pre-eclamptic placenta. This study examined the effect of modulating dietary selenium content in pregnant rats. Rats were fed diets containing no selenium, $239 \mu \mathrm{g} / \mathrm{kg}$ selenium or $1000 \mu \mathrm{g} / \mathrm{kg} \mathrm{selenium,}$ four weeks prior to and following conception. Significant pregnancy-specific increases in systolic blood pressure $(116.4 \pm 5.2 \mathrm{mmHg}$ vs $108 \pm 6.8 \mathrm{mmHg}$ vs $111.4 \pm 4.7 \mathrm{mmHg})$ and proteinuria $(9.68 \pm 2.12 \mu \mathrm{g} / \mathrm{ml} \mathrm{vs} 5.93 \pm 1.59 \mu \mathrm{g} / \mathrm{ml} \mathrm{vs}$ $4.43 \pm 0.96 \mu \mathrm{g} / \mathrm{ml}$ ) were demonstrated in animals fed a selenium free-diet when compared with normal or high selenium diets. Placental weight and pup number were not affected by selenium deprivation, however a significant decrease in the pup weight was evident. Selenium deprivation caused dose-dependent decreases in liver glutathione peroxidase (28.55 \pm $3.82 \mathrm{mmoles} / \mathrm{min} / \mathrm{mg}$ vs $34.68 \pm 8.64 \mathrm{mmoles} / \mathrm{min} / \mathrm{mg})$ and thioredoxin reductase $(2.37 \pm 1.25 \mathrm{U} / \mathrm{mg} \mathrm{vs} 6.68 \pm 1.82 \mathrm{U} / \mathrm{mg})$ activity, whereas superoxide dismutase activity remained constant. Placental activity of these enzymes also decreased leading to oxidative stress as measured by increased lipid peroxides $(17.92 \pm 1.78 \mu \mathrm{moles} / \mathrm{mg}$ vs $8.30 \pm 5.52 \mu \mathrm{moles} / \mathrm{mg})$ and protein carbonyls in tissue extracts from selenium-free animals. These results suggest that selenium deficiency in pregnant rats leads to symptoms similar to those seen in human PET and may provide an experimental model for studying this complex disease. Reproduction (2004) 128 635-641
\end{abstract}

\section{Introduction}

Affecting $6-8 \%$ of all pregnancies, pre-eclampsia (PET) is the leading cause of maternal morbidity in the western world and is characterised by hypertension, proteinuria, edema and platelet aggregation. Despite its prevalence and severity the pathophysiology of this multi-system disorder is still poorly understood. Placental oxidative stress has been shown to be a key feature in the pathogenesis of PET (for reviews see Walsh 1998, Hubel 1999, Redman \& Sargent 2000). Oxidative stress is defined as an imbalance between the cellular generation of reactive oxygen species (ROS) and the capacity of anti-oxidants to prevent oxidative damage. The expression and activity of important anti-oxidant proteins are decreased in placental tissues from pre-eclamptic mothers, resulting in an imbalance between pro-oxidants and anti-oxidants leading to oxidative stress. Two of these anti-oxidant proteins are glutathione peroxidase and thioredoxin reductase, enzymes that have selenocysteine within their active site and are selenium-dependent for activity.

Whole blood and plasma levels of selenium are lower in pregnant women when compared with non-pregnant women (Mihailovic et al. 2000) and decrease as gestation proceeds (Zachara et al. 1993). In 1990, Lu reported an increased incidence of pregnancy-induced hypertension in selenium-deficient regions of China and it was later found that selenium supplementation could be used to lower this high incidence of disease. Furthermore, decreased levels of selenium have been observed in patients with PET (Rayman et al. 2003). In humans, as in other mammals, selenium depletion leads to loss of glutathione peroxidase and thioredoxin reductase activity, although to date no one has examined the placental expression of these proteins during PET and related this to selenium status.

A major limitation of the investigations into the pathophysiology of PET is the fact that the disorder does not occur naturally in animals other than humans and two species of higher order primates, the patas monkey and the lowland gorilla (Zuspan 1991, Faas \& Schuiling 2001). Numerous research groups have developed a variety of rodent models that in one way or another induce similar symptoms to those seen during human PET. These include nitric oxide inhibition (Baylis \& Engels 1992), low dose endotoxin administration (Faas et al. 1994), sympathetic 
nervous system stimulation (Kanayama et al. 1997, Khatun et al. 1999), uteroplacental ischemia (Losonczy et al. 1992), hyperinsulinemia (Podjarny et al. 1998) and spontaneously hypertensive models (Sharkey et al. 2001). In this report we have studied the pregnancies of rats fed a selenium-deficient diet and carried out preliminary biochemical analysis on placental tissues from these animals to demonstrate that changes seen in seleniumdeficient rat pregnancies are similar to those seen in human placental tissues during PET.

\section{Materials and Methods}

Eight week old virgin female Wistar rats were housed at a constant temperature $\left(22^{\circ} \mathrm{C}\right)$ in a $12 \mathrm{~h}$ light dark cycle environment with free access to food and drinking water. Animals were randomised into four groups $(n=6)$ and fed one of three diets that differed in their levels of selenium for 4 weeks. The basal diet was selenium-free, containing $30 \%$ torula yeast, 59\% sucrose, 5\% coconut oil (vitamin $\mathrm{E}$ free), 5\% premixed minerals (Hubbel, Mendel \& Wakeman salt mix, ICN, Seven Hills, Australia) and $1 \%$ premixed vitamins (vitamin diet fortification mixture, ICN). One experimental group received the selenium-free diet whilst another received the same diet supplemented with $1000 \mu \mathrm{g} / \mathrm{kg}$ sodium selenite (Sigma). One group of animals were fed standard rat chow, which contained $239 \mu \mathrm{g} / \mathrm{kg}$ of total selenium. The animals from each diet group were then cycled and mated with fertile males at proestrous, with a positive vaginal smear for sperm the day after proestrous indicating day 0 of pregnancy. The remaining animals continued on their diets as non-pregnant controls.

Urine samples were collected by applying pressure to the bladder and collecting excreted urine with a capillary tube on days 7 and 21 and stored at $-80^{\circ} \mathrm{C}$ before analysis for urinary protein concentrations. Blood pressures were taken three times within $5 \mathrm{~min}$ on days $0,7,14$ and 21 by tail cuff method (ABI Instruments, Sydney, Australia, using a $15 \mathrm{~mm}$ occlusion cuff and pulse transducer.

On day 21 pregnant rats were anesthetised using sodium pentobarbital $(60 \mathrm{mg} / \mathrm{kg} \mathrm{IP})$ and the pups delivered by caesarean section. Placental weight, fetal number and fetal weight were recorded. Placentas and the mother's liver and kidneys were collected, weighed and stored at $-80^{\circ} \mathrm{C}$ before biochemical analysis. The project was approved by the Griffith University Animal Ethics committee.

\section{Processing of tissue samples and protein estimations}

All samples were weighed and homogenized in four volumes of phosphate buffered saline (PBS) containing proteolytic enzyme inhibitors (Complete-Mini, Roche, Mannheim, Germany) using an Ultra-Turex homogeniser (IKA-Werke GMBH, KG Staufen, Germany). Samples were then centrifuged for $30 \mathrm{~min}$ at 4000 r.p.m. and the supernatant collected for biochemical analysis. The protein concentrations of tissue homogenates was determined by the BCA Protein Assay kit (Pierce, Rockford, IL, USA) following the manufacturer's recommended protocols. Urea is an interfering substance for the BCA Protein Assay kit so rat urine samples were analysed using the Coomassie Plus Protein Assay kit (Pierce) following the manufacturer's recommended protocols. Bovine serum albumin (BSA) was used as the protein standard and assayed together with dilutions of placental extracts. Protein concentrations were determined from the standard curve and expressed as $\mu \mathrm{g}$ protein per $\mathrm{ml}$ of tissue extract $(\mu \mathrm{g} / \mathrm{ml})$.

\section{Glutathione Peroxidase Assay}

Glutathione peroxidase activity was determined by a modified method of Paglia and Valentine (1967). Activity was determined spectrophotometrically by coupling the oxidation of glutathione and NADPH using glutathione reductase. Briefly, $900 \mu \mathrm{l}$ of assay mix containing $0.1 \mathrm{M} \mathrm{KPi}$ $(\mathrm{pH}$ 7.0), $2 \mathrm{mM}$ EDTA, $0.5 \mathrm{U} / \mathrm{ml}$ glutathione reductase, $10 \mathrm{mM}$ glutathione and $0.3 \mathrm{mM}$ reduced $\mathrm{NADPH}$ was placed into a Varian CARY 50 spectrophotometer (Varian Palo Alto, CA, USA) set at $340 \mathrm{~nm}$. Diluted tissue extract (50 $\mu$ l of $1 / 10$ dilution) was added to the cuvette along with $50 \mu \mathrm{l}$ of $20 \mathrm{mM}$ tert-butyl hydroperoxide, a suitable substrate for glutathione peroxidase. The decrease in A340 was determined over a $3 \mathrm{~min}$ period and rate calculations were performed using Varian Cary software. Glutathione peroxidase activity was standardised against protein concentrations and expressed as mmoles per minute per mg of protein (mmoles/min/mg).

\section{Thioredoxin reductase assay}

Thioredoxin reductase activity was measured spectrophotometrically in a 96-well plate using the method of Holmgren and Bjornstedt (1995). This assay measures the thioredoxin reductase- and NADPH-dependent reduction of insulin with and without thioredoxin. Briefly, $20 \mu \mathrm{l}$ of the $1 / 10$ diluted tissue extracts were added to $120 \mu$ l of assay mix containing $50 \mathrm{mM} \mathrm{KPi}, 5 \mathrm{mM}$ EDTA and $0.324 \mathrm{mg} / \mathrm{ml}$ insulin in a 96 well plate. Recombinant thioredoxin $(10 \mu \mathrm{l}$ of $1.4 \mathrm{mg} / \mathrm{ml})$ was added to one well of each sample, while a further $10 \mu \mathrm{l}$ of assay mix was added to the second well to measure background absorbance. Each sample was assayed in at least duplicate. After incubation at $37^{\circ} \mathrm{C}$ for $20 \mathrm{~min}$ the reaction was

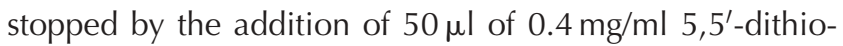
bis 2-nitrobenzoic acid (DTNB) in $6 \mathrm{M}$ guanidine- $\mathrm{HCl}$. The plate was incubated for $10 \mathrm{~min}$ at room temperature in the dark and plates were then read at $412 \mathrm{~nm}$. Thioredoxin reductase activity was determined by subtracting the level of spontaneous insulin reduction from the thioredoxin-, thioredoxin reductase-, NADPH-dependent reduction of insulin. Thioredoxin reductase activity was expressed as units per gram of protein (U/mg). 


\section{Superoxide dismutase assay}

Total superoxide dismutase (SOD) activity was measured in triplicate, spectrophotometrically in a 96-well plate using the method of Ahmed et al. (2003). This assay is based upon the inhibition of pyrogallol oxidation, with one unit of SOD activity the amount that causes 50\% inhibition of the oxidation of pyrogallol. SOD activity was measured every $5 \mathrm{~min}$ over $1 \mathrm{~h}$ at $405 \mathrm{~nm}$ for $20 \mu \mathrm{l}$ of $1 / 100$ dilution of placental tissue extract with $180 \mu \mathrm{l}$ of Tris-cacodylic acid buffer $(0.05 \mathrm{M}, \mathrm{pH}$ 8.2) containing $0.001 \mathrm{M}$ diethylenetriamine pentaacetic acid (DTPA) and $0.2 \mathrm{mM}$ pyrogallol. Superoxide dismutase activity was determined from the time-dependent inhibition of pyrogallol and expressed as units per milligram of protein $(\mathrm{U} / \mathrm{mg})$.

\section{Lipid peroxidation assay}

Lipid peroxidation levels in tissue extracts were determined using a lipid peroxidation assay kit (Calbiochem, San Diego, CA, USA), following the manufacturer's recommended protocol. This assay determines lipid peroxidation levels through the reaction of malondialdehyde (MDA) and 4-hydroxy-2(E)-nonenal (4-HNE) with chromogenic reagent 1-methyl-2-phenylindole at $45^{\circ} \mathrm{C}$, which results in the production of a stable chromophore with maximal absorbance at $586 \mathrm{~nm}$. Tissue extracts were incubated for $40 \mathrm{~min}$ with 1-methyl-2-phenylindole and $10 \mathrm{M}$ methanesulphonic acid at $45^{\circ} \mathrm{C}$, samples were then cooled on ice and centrifuged at $15000 \mathrm{~g}$ for $10 \mathrm{~min}$ to obtain clear supernatant samples that were read at $586 \mathrm{~nm}$. 4-HNE was used to establish a standard curve, the gradient of which indicated the molar extinction coefficient used in the equation $[\mathrm{MDA}+4-\mathrm{HNE}]=$ (sample absorbance) $\times 5 / \varepsilon$ with sample lipid peroxidation concentrations expressed as $\mu$ moles $/ \mathrm{mg}$ protein.

\section{Protein carbonyl assay}

Placental extracts were analysed for protein carbonyl concentrations by the previously described ELISA method of Buss et al. (1997). This assay measures protein carbonyls in biological samples after reaction with 2,4-dinitrophenyl hydrazine (DNP). Samples are then non-specifically adsorbed onto Nunc Immunosorb plates where protein bound DNP was detected with anti-DNP-biotin-antibody labelled with streptavidin-biotinylated horseradish peroxidase. Finally, reaction with o-phenylenediamine and hydrogen peroxide in $50 \mathrm{mM} \mathrm{NaHPO}$ plus citric acid resulted in color development after $25 \mathrm{~min}$, with absorbances read at $450 \mathrm{~nm}$ after stopping the reaction with sulphuric acid. Each sample was analysed in triplicate and samples were quantified by comparison with oxidized BSA standards.

\section{Data analysis}

All data was processed using the Graph Pad Prism version 3.0 (Graph Pad Software Inc, San Diego, CA, USA) statistical package with $P<0.05$ considered significant. Oneway analysis of variance with Newman-Keuls method for pair-wise multiple comparisons was used for analysis and Grubb's test for outliers was the basis for exclusion where appropriate.

\section{Results}

\section{Physiological data}

The elimination of selenium from the diet of rats over a 4 week period prior to conception resulted in a significant pregnancy-dependent increase in systolic blood pressure from $109.7 \pm 6.80 \mathrm{mmHg}$ in non-pregnant animals to $116.4 \pm 5.21 \mathrm{mmHg}$ at gestation week $3 \quad(P<0.001)$ (Fig. 1A). Pregnant rats fed a standard diet containing $239 \mu \mathrm{g} \mathrm{Se} / \mathrm{kg}$ or a high selenium diet $(1000 \mu \mathrm{g} \mathrm{Se} / \mathrm{kg})$ did
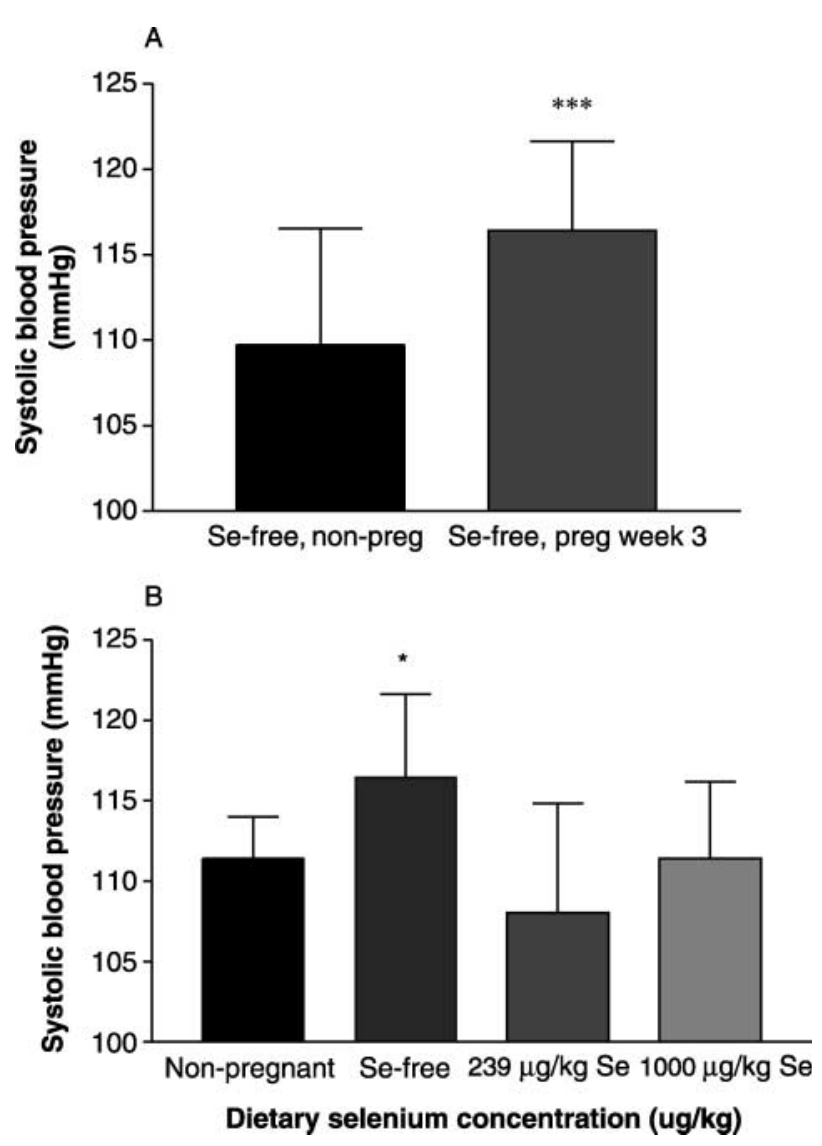

Figure 1 (A) Effect of pregnancy on systolic blood pressure in rats fed a selenium-free diet, demonstrating a significant pregnancy-dependent increase in systolic blood pressure as a result of a selenium deficiency $(* * * P<0.001)$. (B) Effect of varying the dietary selenium intakes on systolic blood pressure in pregnant rats. A diet deficient in selenium significantly increased systolic blood pressure when compared with both $239 \mu \mathrm{g} / \mathrm{kg}$ and $1000 \mu \mathrm{g} / \mathrm{kg}$ selenium diets. $(* P<0.05)$. 


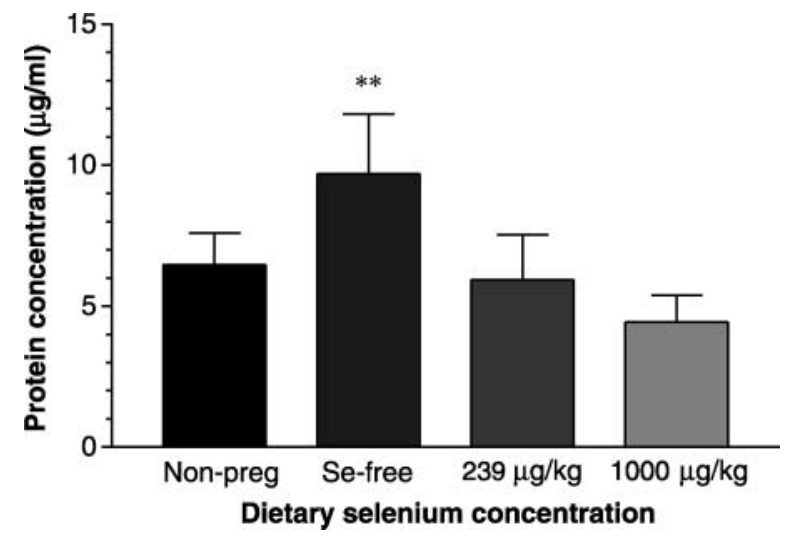

Figure 2 Effect of dietary selenium concentration on urinary protein concentration in pregnant and non-pregnant rats: a pregnancy-dependent increase in urinary protein concentration was observed in selenium-deficient rats $(* * P<0.01)$.

not display this increase (Fig. 1B). Systolic blood pressures for rats fed the selenium-free diet $(116.4 \pm 5.21 \mathrm{mmHg})$ increased significantly when compared with week three blood pressures of rats fed both the normal diet (108 $\pm 6.80, P=0.014)$ and the high selenium diet (111.4 $\pm 4.78, P<0.01$ ) (Fig. 1B). Significantly increased urinary protein concentrations were measured in pregnant rats with the selenium-free diet (Fig. 2). Non-pregnant animals on the selenium free diet demonstrated mean urinary protein concentrations of $6.46 \pm 1.13 \mu \mathrm{g} / \mathrm{ml}$ that, when compared with pregnant animals on the same diet, demonstrated significantly increased urinary protein concentrations of $9.68 \pm 2.12 \mu \mathrm{g} / \mathrm{ml}$ at term $(P<0.01)$, an increase not seen in other diet groups. The comparison of term urinary protein concentrations for the selenium-free diet $(9.68 \pm 2.12 \mu \mathrm{g} / \mathrm{ml})$ with both the standard $(5.94 \pm 1.60 \mu \mathrm{g} / \mathrm{ml}, \quad P<0.01)$ and high selenium $(4.43 \pm 0.96 \mu \mathrm{g} / \mathrm{ml}, P<0.001)$ treatment groups demonstrated significant differences (Fig. 2). There was no significant difference in placental weight or pup number between the groups (data not shown). However, pup

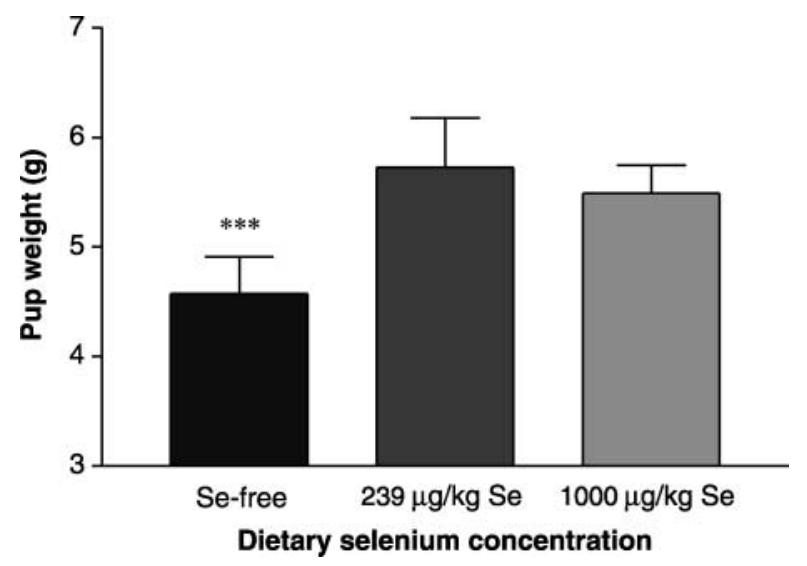

Figure 3 Effect of dietary selenium concentration on pup weights, illustrating that a selenium deficient diet resulted in significantly decreased pup weights $(* * * P<0.001)$. weight was significantly reduced in rats from the selenium-free group $(4.57 \pm 0.34$ grams $)$ when compared with both the standard diet group (5.726 \pm 0.452 grams, $P<0.001)$ and the high selenium group (5.49 \pm 0.26 grams, $P<0.001$ ) (Fig. 3).

\section{Liver concentrations of anti-oxidant proteins}

Selenium deficiency resulted in a significant reduction in the liver concentrations of selenium-dependent anti-oxident proteins. Thioredoxin reductase activity (Table 1) was significantly reduced for the selenium-free pregnant group $(2.37 \pm 1.25 \mathrm{U} / \mathrm{mg}$ protein, $P<0.001)$ when compared with the pregnant animals on the standard diet $(6.68 \pm 1.82 \mathrm{U} / \mathrm{mg}$ protein). Increasing dietary selenium intake to $1000 \mathrm{ug} / \mathrm{Kg}$ of food during pregnancy was shown to significantly increase liver thioredoxin reductase activity $(12.13 \pm 1.94 \mathrm{U} / \mathrm{mg}$ protein, $P<0.05)$. There was a significant difference $(P<0.05)$ between pregnant $(6.681 \pm 1.82 \mathrm{U} / \mathrm{mg}$ protein) and non-pregnant animals $(12.45 \pm 6.16 \mathrm{U} / \mathrm{mg}$ protein) on the standard rat chow diet, indicating that pregnancy may be associated with a decrease in systemic anti-oxidant activity (Table 1).

Glutathione peroxidase activity in liver homogenates (Table 1) was significantly reduced in pregnant animals on selenium-free diets $(28.55 \pm 3.82 \mathrm{mmoles} / \mathrm{min} / \mathrm{mg})$ when compared with pregnant animals on normal diets (34.68 $\pm 8.64 \mathrm{mmoles} / \mathrm{min} / \mathrm{mg}, P<0.001)$. Increasing the selenium content of the diet of pregnant rats increased the liver activity of glutathione peroxidase to $62.26 \pm 8.10 \mathrm{mmoles} / \mathrm{min} / \mathrm{mg}(P<0.001)$. When compared with the non-pregnant control group (49.10 \pm $9.83 \mathrm{mmoles} / \mathrm{min} / \mathrm{mg}$ ) there was a significant decrease in glutathione peroxidase activity in those animals on a standard rat chow diet when they became pregnant (34.68 \pm $8.64 \mathrm{mmoles} / \mathrm{min} / \mathrm{mg}$, $P<0.01)$.

There were no significant changes in superoxide dismutase levels in animals receiving various selenium diets, whether pregnant or not (Table 1).

\section{Placental concentrations of anti-oxidant proteins}

There was no significant difference in placental thioredoxin reductase activity when comparing the selenium-free animals $(11.06 \pm 1.84 \mathrm{U} / \mathrm{mg}$ protein) with those on a standard diet containing $239 \mu \mathrm{g} / \mathrm{Kg}$ selenium $(11.29 \pm 3.14 \mathrm{U} / \mathrm{mg})$. Placental thioredoxin reductase activity was significantly increased to $17.01 \pm 4.09 \mathrm{U} / \mathrm{mg}$ protein $(P<0.05)$ with selenium supplementation of $1000 \mu \mathrm{g} / \mathrm{kg}$ food (Table 1). A similar trend was also seen when comparing glutathione peroxidase activity for the high selenium group (54.34 \pm $6.73 \mathrm{mmoles} / \mathrm{min} / \mathrm{mg}$ protein) with the selenium free (33.33 $\pm 6.11 \mathrm{mmoles} / \mathrm{min} / \mathrm{mg}$ protein, $P<0.001)$ and standard diet $(40.52 \pm 4.87 \mathrm{mmoles} / \mathrm{min} / \mathrm{mg}$ protein, $P<0.01)$ groups, with no significant difference between the latter two groups (Table 1). There was no significant difference in the level of placental superoxide dismutase activity in the placentae of animals from each dietary 
Table 1 The effect of dietary selenium on anti-oxidant proteins in rat liver and placenta.

\begin{tabular}{|c|c|c|c|c|}
\hline & $\begin{array}{c}\text { Non-pregnant } \\
\text { (mean } \pm \text { S.D.) } \\
n=6\end{array}$ & $\begin{array}{c}\text { Selenium-free } \\
\text { (mean } \pm \text { S.D.) } \\
n=6\end{array}$ & $\begin{array}{c}239 \mu \mathbf{g ~ S e} / \mathbf{k g} \\
(\text { mean } \pm \text { S.D. }) \\
n=6\end{array}$ & $\begin{array}{c}1000 \mu \mathbf{g ~ S e} / \mathbf{k g} \\
(\text { mean } \pm \text { S.D. }) \\
n=6\end{array}$ \\
\hline \multicolumn{5}{|l|}{ Liver } \\
\hline $\begin{array}{l}\text { Glutathione peroxidase } \\
\text { (mmoles/min/mg protein) }\end{array}$ & $49.10 \pm 9.83$ & $28.55 \pm 3.82^{a_{* * *}}$ & $34.68 \pm 8.64^{\mathrm{b}_{* *}}$ & $62.26 \pm 8.10^{\mathrm{a}_{* * *}}$ \\
\hline $\begin{array}{l}\text { Thioredoxin reductase } \\
\text { (U/mg protein) }\end{array}$ & $12.45 \pm 6.16$ & $2.37 \pm 1.25^{\mathrm{a}_{* * *}}$ & $6.68 \pm 1.82^{b_{*}}$ & $12.13 \pm 1.94^{\mathrm{a}_{*}}$ \\
\hline $\begin{array}{l}\text { Superoxide dismutase } \\
\text { (U/mg protein) }\end{array}$ & $2.37 \pm 0.41$ & $2.51 \pm 0.28$ & $2.25 \pm 0.89$ & $2.57 \pm 0.38$ \\
\hline \multicolumn{5}{|l|}{ Placenta } \\
\hline $\begin{array}{l}\text { Glutathione peroxidase } \\
\text { (mmoles/min/mg protein) }\end{array}$ & - & $33.33 \pm 6.11$ & $40.52 \pm 4.87$ & $54.34 \pm 6.73^{\mathrm{a}, \mathrm{c}_{* * *}}$ \\
\hline $\begin{array}{l}\text { Thioredoxin reductase } \\
\text { (U/mg protein) }\end{array}$ & - & $11.06 \pm 1.84$ & $11.29 \pm 3.14$ & $17.01 \pm 4.09^{\mathrm{a}_{*}}$ \\
\hline $\begin{array}{l}\text { Superoxide dismutase } \\
\text { (U/mg protein) }\end{array}$ & - & $2.07 \pm 0.14$ & $2.23 \pm 0.29$ & $2.44 \pm 0.24$ \\
\hline
\end{tabular}

$* P<0.05, * * P<0.01, * * * P<0.001,{ }^{\mathrm{a}}$ Compared to $239 \mu \mathrm{g}$ Se/kg group, ${ }^{\mathrm{b}} \mathrm{Compared}$ to non-pregnant group, ${ }^{\mathrm{c}}$ Compared to the selenium-free group.

group although there was a trend towards an increase in activity correlating with higher selenium intakes (Table 1).

\section{Placental oxidative stress}

The oxidative state of placental tissues from all diet groups was measured via lipid peroxide and protein carbonyl concentrations. Placental lipid peroxidation was significantly increased with the elimination of selenium from the diet $(17.92 \pm 1.78 \mu$ moles $/ \mathrm{mg})$ with a significant difference in MDA + 4-HNE concentrations when compared with both the standard $(8.30 \pm 5.52 \mu$ moles $/ \mathrm{mg}$ protein, $P<0.05)$ and high selenium (7.81 $\pm 3.79 \mu$ moles $/ m g$ protein, $P<0.05$ ) diet groups (Fig. 4A). Protein carbonyl concentrations were elevated in the placenta by the elimination of selenium from the diet, however this increase did not reach significance (Fig. 4B).

\section{Discussion}

In 1990 Lu observed that selenium levels in women with pregnancy-induced hypertension $(\mathrm{PIH})$ were lower than women experiencing a normotensive pregnancy. It was later shown that selenium supplementation could be used to lower the incidence of PIH in a small group of pregnant women with high risk factors (Han \& Zhou 1994). In 1996 Rayman et al. detected no difference in the serum levels of selenium in patients with PET when compared with non pre-eclamptic pregnancies, however in a later report the same authors measured the selenium concentrations in the toe-nails of pregnant women and found a significant correlation between pre-eclamsia and decreased selenium status prior to pregnancy (Rayman et al. 2003). Many of the studies examining selenium status during pregnancy have noted a decrease as gestation proceeds, presumably due to increased metabolic demand for selenium and plasma volume expansion (Zachara et al. 1993). Given the evidence suggesting that hypertensive disorders of
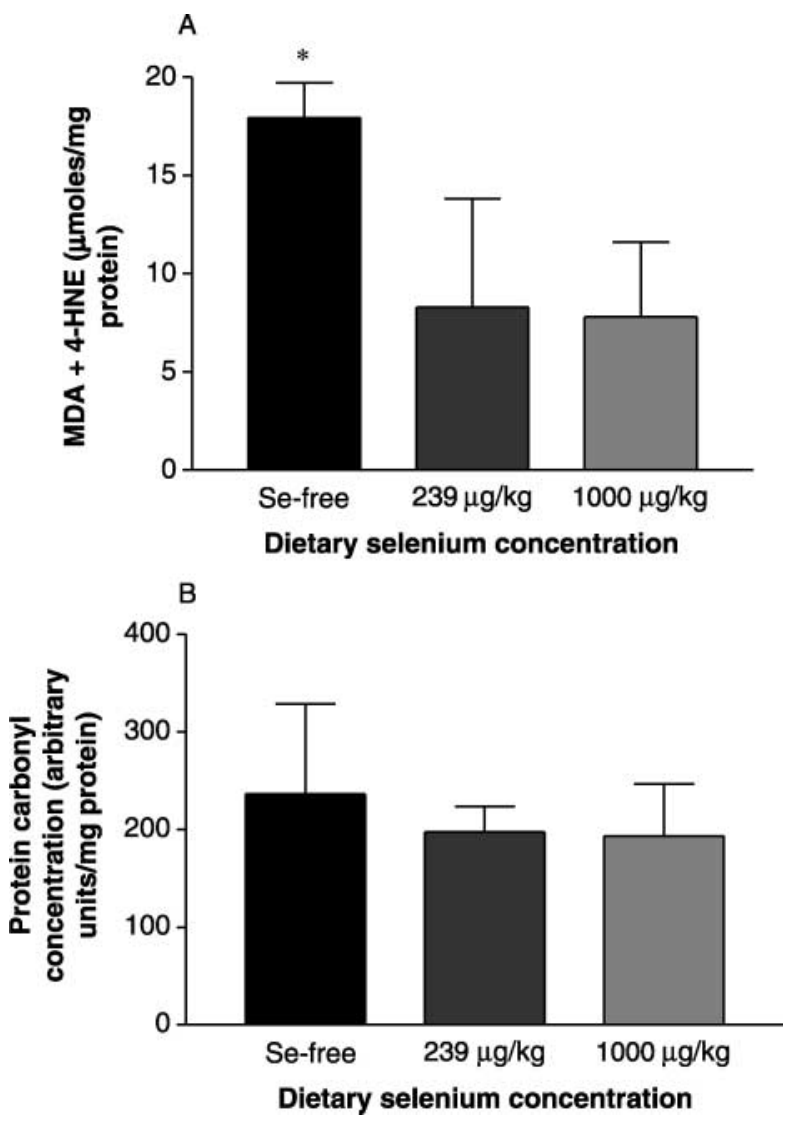

Figure 4 (A) Effect of dietary selenium concentration on placental lipid peroxidation in pregnant rats. A selenium-deficient diet resulted in a significant increase in placental levels of lipid peroxides $(* P<0.05)$. (B) Effect of dietary selenium concentration on placental protein carbonyl concentrations in rats. An elevation in protein carbonyl concentrations was observed after the elimination of selenium from the diet that did not reach significance. 
pregnancy are associated with low selenium intake, we decided to examine the impact of varying selenium diets on pregnant rats.

Rats were fed diets containing $0 \mu \mathrm{g} / \mathrm{kg}, 239 \mu \mathrm{g} / \mathrm{kg}$ and $1000 \mu \mathrm{g} / \mathrm{kg}$ selenium for 4 weeks prior to mating. There was no increase in either blood pressure or proteinuria during this period. Animals from each dietary group were mated and their blood pressures observed weekly from day 0 to day 21 of pregnancy. There was a significant increase in the systolic blood pressure of those animals on a selenium-free diet when compared with animals on a normal rat diet or a high selenium diet. We also observed an increase in proteinuria in these animals, suggesting that selenium deprivation leads to a pre-eclamptic like condition in rats deprived of selenium. We also examined the outcomes from these pregnancies and noted a decrease in pup weights in the selenium-free group but no change in pup number or placental weight.

In order to explore the biochemistry underlying these physiological changes we examined the liver activity of key anti-oxidant proteins thioredoxin reductase, glutathione peroxidase and superoxide dismutase. There was a dose-dependent relationship between selenium intake and liver activity of thioredoxin reductase and glutathione peroxidase but no change in superoxide dismutase activity. This is to be expected as thioredoxin reductase and glutathione peroxidase are selenium-dependent enzymes and we have shown in other studies that dietary selenium intake is a simple and applicable method of altering the endogenous activity of these proteins (Venardos et al. 2004). An interesting observation during these studies was the significant decrease in both thioredoxin reductase and glutathione peroxidase activity in pregnant animals fed a standard diet compared with non-pregnant animals on the same diet. This suggests that pregnancy is associated with decreased anti-oxidant protection, perhaps due to an increased demand for selenium. In humans, selenium levels decrease as gestation proceeds (Zachara et al. 1993).

It is now generally accepted that human PET is associated with an increase in placental oxidative stress (reviewed in Redman \& Sargent 2001). The levels of reactive oxygen species, products of increased biological oxidation such a lipid peroxides, protein carbonyls and nitro-tyrosine residues are all elevated in pre-eclamptic placentae. Recent work from this laboratory and that of others (Walsh \& Wang 1993, Wiktor et al. 2000) has shown that key anti-oxidants such as thioredoxin reductase and glutathione peroxidase are decreased in placental tissue from pre-eclamptics, adding to the oxidative stress in these tissues which may lead to increased apoptosis and even necrosis. In this study we found that animals on selenium-free diets and those on normal diets had decreased placental expression of thioredoxin reductase and glutathione peroxidase when compared with animals supplemented with $1000 \mu \mathrm{g} / \mathrm{kg}$ selenium. Perhaps selenium supplementation could be a simple applicable method of alleviating placental oxidative stress in humans suffering from PET as has been shown to be the case in the Chinese study on PIH women (Han \& Zhou 1994).

In rats on selenium-free diets there was a significant increase in placental oxidative stress as measured by the lipid peroxide and protein carbonyl content. The addition of selenium to the diets decreased this oxidative stress but this did not correspond to the increased expression of thioredoxin reductase and glutathione peroxidase. The expression of these proteins was similar in animals on selenium-free and normal diets yet the level of lipid peroxides was higher in selenium-free animals only. The level of protein carbonyls, a marker of protein oxidation, followed a similar trend but did not reach statistical significance. This suggests that another selenium dependent protein may be responsible for this decrease in selenium replete animals, perhaps selenoprotein $P$ that has been shown to act as an extra-cellular glutathione peroxidase (Saito et al. 1999).

Research on PET has been hindered in the past by the lack of a suitable animal model of this complex disease. Various rodent models of PET have been explored, all of which display various symptoms analogous to human PET, but do not display the oxidative changes in the placental compartment that is a key feature of the disease. In this study we have shown that selenium deprivation is able to modulate the endogenous expression of key anti-oxidant proteins, leading to a state of placental oxidative stress resulting in physiological changes in pregnant rats similar to those seen during human PET.

\section{References}

Ahmed H, Schott EJ, Gauthier JD \& Vasta GR 2003 Superoxide dismutases from the oyster parasite Perkinsus marinus: purification, biochemical characterization, and development of a plate microassay for activity. Analytical Biochemistry 318 $132-141$.

Baylis C \& Engels K 1992 Adverse interactions between pregnancy and a new model of systemic hypertension produced by chronic blockade of endothelial derived relaxing factor (EDRF) in the rat. Clinical Experiments in Hypertension B11 117-129.

Buss H, Chan TP, Sluis KB, Domigan NM, Winterbourn CC 1997 Protein carbonyl measurement by a sensitive ELISA method. Free Radical Biology and Medicine 23 361-366.

Di Trapani G, Perkins AV \& Clarke FM 1998 Production and secretion of thioredoxin from transformed human trophoblast cells. Molecular Human Reproduction 4 369-375.

Faas MM \& Schuiling GA 2001 Pre-eclampsia and the inflammatory response. European Journal of Obstetrics and Gynecology and Reproductive Biology 95 213-217.

Faas MM, Schuiling GA, Baller JFW, Visscher CA \& Baller WW 1994 A new animal model for human preeclampsia: ultra-low-dose endotoxin infusion in pregnant rats. American Journal of Obstetrics and Gynecology 171 158-164.

Han L \& Zhou SM 1994 Selenium supplement in the prevention of pregnancy induced hypertension. Chinese Medical Journal 107 870-871.

Holmgren A \& Bjornstedt M 1995 Thioredoxin and thioredoxin reductase. Methods in Enzymology 252 199-208.

Hubel CA 1999 Oxidative stress in the pathogenesis of preeclampsia. Proceedings for the Society of Experimental Biological Medicine $222222-235$. 
Kanayama N, Tsujimura R \& She L 1997 Cold-induced stress stimulates the sympathetic nervous system, causing hypertension and proteinuria in rats. Journal of Hypertension 15 383-389.

Khatun S, Kanayama N, Belayet HM, Masui M, Sugimura M, Kobayashi T \& Terao T 1999 Induction of preeclampsia like phenomena by stimulation of sympathetic nerve with cold and fasting stress. European Journal of Obstetrics and Gynecology and Reproductive Biology 86 89-97.

Knapen MF, Peters WH, Mulder TP, Merkus HM, Jansen JB \& Steegers EA 1999 Glutathione and glutathione-related enzymes in decidua and placenta of controls and women with pre-eclampsia. Placenta $20541-546$.

Losonczy G, Brown G \& Venuto RC 1992 Increased peripheral resistance during reduced uterine perfusion pressure hypertension in pregnant rabbits. American Journal of Medical Science 303 $233-240$.

Lu BY 1990 Changes of selenium in patients with pregnancy induced hypertension. Chinese Journal of Obstetrics and Gynecology 25 325.

Mihailovic M, Cvetkovic M, Ljubic A, Kosanovic M, Nedeljkovic S, Jovanovic I \& Pesut O 2000 Selenium and malondialdehyde content and glutathione peroxidase activity in maternal and umbilical cord blood and amniotic fluid. Biological and Trace Element Research 73 47-54.

Paglia DE \& Valentine WN 1967 Studies on the quantitative and qualitatitive characterisation of erythrocyte glutathione peroxidase. Journal of Laboratory and Clinical Medicine $\mathbf{7 0}$ 158-169.

Podjarny E, Bernheim J \& Katz B 1998 Chronic exogenous hyperinsulinemia in pregnancy: a rat model for pregnancy induced hypertension. Journal of the American Society of Nephrology 9 9-13.

Rayman MP, Abou-Shakra FR, Ward NI \& Redman CW 1996 Comparison of selenium levels in pre-eclamptic and normal pregnancies. Biological and Trace Elements Research 55 9-20.

Rayman MP, Bode P \& Redman CWG 2003 Low selenium status is associated with the occurence of the pregnancy disease preeclampsia in women from the United Kingdom. American Journal of Obstetrics and Gynecology 189 1343-1349.
Redman CWG \& Sargent IL 2000 Placental debris, oxidative stress and pre-eclampsia. Placenta 21 597-602.

Redman CWG \& Sargent IL 2001 The pathogenesis of pre-eclampsia. Gynecology Obstetrics and Fertility 29 518-522.

Saito Y, Hayashi T, Tanaka A, Watanabe Y \& Suzuki M 1999 Selenoprotein $\mathrm{P}$ in human plasma as an extracellular phospholipid glutathione peroxidase. Journal of Biological Chemistry $\mathbf{2 7 4}$ 2866-2871.

Sharkey LC, McCune SA, Yuan O, Lange C \& Fray J 2001 Spontaneous pregnancy-induced hypertension and intrauterine growth restriction in rats. American Journal of Hypertension 14 $1058-1066$

Venardos K, Harrison G, Headrick J \& Perkins A 2004 Effects of dietary selenium on glutathione peroxidase and thioredoxin reductase activity and recovery from cardiac ischemia-reperfusion. Journal of Trace Elements in Medicine and Biology (In Press).

Walsh SW 1998 Maternal-placental interactions of oxidative stress and antioxidants in preeclampsia. Seminars of Reproductive Endocrinology 16 93-104.

Walsh SW \& Wang Y 1993 Deficient glutathione peroxidase activity in preeclampsia is associated with increased placental production of thromboxane and lipid peroxides. American Journal of Obstetrics and Gynecology 169 1456-1461.

Wiktor H, Kankofer M, Zrubek H \& Kotarski J 2000 Glutathione peroxidase activity in normal and preeclamptic placentas. Ginekologia Polska 71 799-803.

Zachara BA, Wardak C, Didkowski W, Maciag A \& Marchaluk E 1993 Changes in blood selenium and glutathione concentrations and glutathione peroxidase activity in human pregnancy. Gynecologic and Obstetric Investigation 35 12-17.

Zuspan FP 1991 New concepts in the understanding of hypertensive diseases during pregnancy: An overview. Clinics in Perinatology $18653-659$.

Received 1 April 2004

First decision 27 May 2004

Accepted 22 June 2004 